\title{
Design and Production of Rotary Type Machine for Chop Up Organic Waste Plantation
}

\author{
Wenny Marthiana ${ }^{1 *}$, Duskiardi ${ }^{1}$, Rizky Arman ${ }^{1}$, Yovial Mahyoedin ${ }^{1}$, Dedi Wardiyanto ${ }^{2}$. \\ ${ }^{1}$ Department of Mechanical Engineering, Universitas Bung Hatta \\ ${ }^{2}$ Department of Mechanical Engineering, Universitas Muhammadiyah Sumatera barat
}

\begin{abstract}
Agricultural organic waste chopping machine are tools that can be used to chop leaves, twigs and could be used to help farmers in processing of the agricultural disposal products such as stalks and corn stalks, cassava stems, rice stalks in order to accelerate farmers in processing of those disposal in order that the plantation land can be prepared immediately for subsequent cultivation, as well as the chopped products can be reused for various purposes such as animal feeds and composts fertilizer. The research of this engineering method is carried out with the following stages: (1) study of the characteristics of several organic wastes to be enumerated, (2) analysis of the Chopping machine elements, consists of Chopping Blades, the house of the chopper blades, hopper, frame and transmission system. (3) A Prototype chop up mechanism manufacturing. And (4) Functional testing machine. The Copping Machine design resume as follows: Production capacity of enumeration $220 \mathrm{~kg}$ / hour. The cutting mechanism uses 2 static blades and 6 rotary blades. Transmission system using Belt-Pulley mechanism. The $24 \mathrm{Hp}$ Diesel engine is used.
\end{abstract}

\section{Introduction}

Waste from organic agriculture such as stems, leaves, generally still reusable, for example for animal feed, and fertilizer, unfortunately agricultural waste is not all being utilized by farmers, the causes are: a) generally farmers burn food crops waste as soon as it will be done soil processing, b) crop waste is kamba so it makes difficulty for farmers to transport in large quantities to be given to livestock, and generally agricultural land is far enough from farmers' settlements so that they require transportation costs, c) unavailability of food crop storage, and farmers are unwilling to store / accumulate waste around the house / under the house for fear of fire hazard, d) breeders assume that the availability of forage in the yard, garden, rice field is still sufficient as animal feed [1]. Most of the corn waste can be used as feed ingredients. With a touch of simple technology, the waste can be converted into nutritious feed and energy source for livestock [2]. Beside green feed agricultural waste can also be used as animal feed. Agricultural waste is a potential local feed for supporting livestock development especially in agriculture-based areas [3].

\footnotetext{
* Corresponding author: wenny ma@yahoo.com
} 
The bad management of agricultural waste can lead to a decrease in agricultural productivity in the fulfillment of food needs; therefore, appropriate handling the rest of this farm is very important and should be of concern [4]. To Burn the rest of the farm is common practice in waste management and as a quick way, as consequences that method causing smoke pollution [5], therefore, the management of agricultural waste should not be burned but in other ways such as by reducing the volume to be easily carried or processed into other uses, the process is by chopping. Based on the research, the absorption of Carbon content in the soil was found to be better when the soil was fed with corn stalks rather than the burning of corn stems. [6] In order to cultivate large quantities of agricultural waste and the limited time and manpower to manage agricultural waste efficient and quick, so the mechanization application is necessarily

Various tools for treating plantation waste have been widely available, such as the application of hammer mill model crusher [7]. Reel type elephant grass chopper machine [8]. Bionic Saw Blade for Corn Stalk Cutting mechanism, this machine type apply a serrated Insisivus design [9]. The schered blade mechanism for cutting coconut midrib [10] and many more. Since the agricultural types and wastes are various, whether influenced by the local conditions or influenced by the price of agricultural commodities, it becomes an advantage if the process tool can be used for several type of raw materials. The difference of the tool in this research is the design of the enumerator machine that can be used for various organic materials such as corn cobs, corn stalks, lumps of manure dried. The result of such shrimp can be used for various purposes, such as cattle feed mixture, corncob mixed flakes, corn stalk can be used as compost, dried livestock debris can be used directly as ready-made manure. Several studies have shown that corn stover results can be used as a source of renewable energy, and is an abundant gold mine for farmers.

Consideration of product design criteria for agricultural waste include: the physical properties of the material to be chopped that is shear stress of the cutting materials and the mechanical properties of the enumerator machine, mechanical properties of the machine are Machine Capacity, component dimensions and cutting power requirements.

\section{Methodology}

Research Phase:

Research phase as described in Figure 1 below

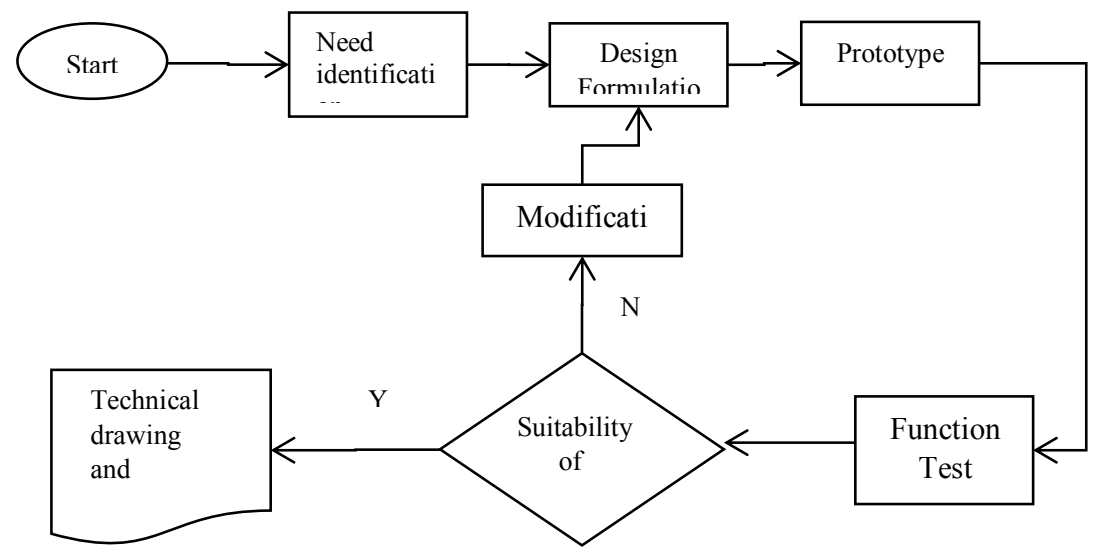

Fig 1. The Research Flow 
A. Identification of needs. Based on the problems faced by the farmers of crops in general. That is to clear the land fields from the organic residues of the harvest quickly and the processed of residual organic products can be reused as organic fertilizer.

B. Formulation of Design. This stage is the crystallization of ideas. In this phase, the formulation of the design specified product specifications desired as the identification needs. Then continue with machine components design. The outputs of this stage are Machine Technical drawings and components specification.

C. Prototype construction. Based on engineering drawings, then the machine prototype was created. The Machine prototype was processed in production process Laboratory of Universitas Bung Hatta Padang

D. Functional testing. This test is performed to see if all components can be unified and whether the machine can function as design accordingly. Where the prototype is appropriate to the design, next the engineering drawings and technical specifications are defined. While not, then Design modification is needed. .

E. Design Modification. This phase is done when there is a mismatch between functional design and machine operation at run time.

F. Technical Drawing and Specification phase of Preparation of engineering drawings and product specifications to be used for further production purposes.

\section{Results and Discussion}

\subsection{Unit Design Enumerator}

cutting knifes being used are a Plate type knife, which is composed of 2 stationary blades and 6 rotary blades. This knife used is taken from paper knife of paper cutting machine that is no longer used. Knife material is S50C, placed with a slope of $5^{0}$ from the cutting mechanism shaft. The cutting slope is expected that cutting process will happen as the shearing process. The Blades position as shown in Figure 2.

\subsection{Frame Design.}

The Construction Frame is designed to withstand cutting mechanism and power engine as well. The Frame construction dimension is $740 \mathrm{~mm}$ in long, $660 \mathrm{~mm}$ in wide, $834 \mathrm{~mm}$ in high. The construction material are the iron elbow and iron UNP. [6-8].

\subsection{The Hopper design}

Hopper, use as a feeding unit is part of a chopping machine that serves material cutting into the blade housing. The cutting material is fed manually through the hopper from the top side. The hopper dimensions are Length $468 \mathrm{~mm}$, Width $250 \mathrm{~mm}$, Height $235 \mathrm{~mm}$

\subsection{Filter Design}

Screening is used to obtain the uniform and smallest possible results, since the organic material of the enumeration will be used as raw material for organic fertilizer then. To satisfy the cutting material can be used in the manufacture of fertilizer in accordance with the desire to quickly decay, the dimensions of the enumeration results are kept to a minimum Fig. 3 
The Mechanism design can be seen as follow

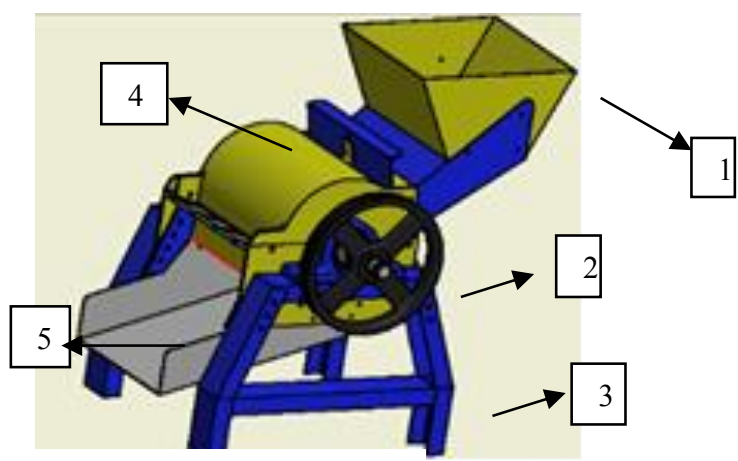

Fig 2 Information.

1. Hopper

2. Pulley

3. Frame

4. Casing Blade

5. Chute

Fig 2. Chopping machine

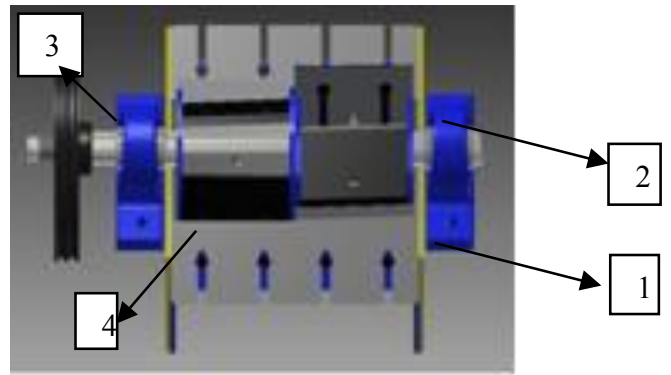

Fig 3 information

1. Stationary Blade

2. Rotary Blade

3. Pulley

4. Bearing

Fig 3. Chopping Blade

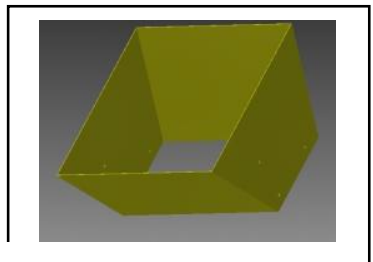

Fig 4. Hopper

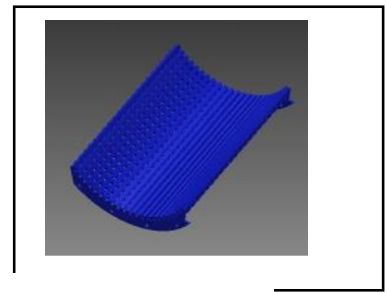

Fig 5. Screening

\subsection{Chopping machine Work mechanism}

The working mechanism is describe as follows :

1. When the main drive motor (diesel motor) is turned on, the pulley of the primarily driving motor transmits the spin to the pulley of the enumerator mechanism through the v-belt belt.

2. Pulley then rotates the dynamic knife shaft.

3. While the organic material is inserted through the hopper, the chopping knife will cut the material when the rotary blade meets with the stationary blade.

4. Corn stover or any other material had been cooped then will be filtered by a filter plate or screen in the bottom of the machine. Screening size is a hole of $5 \mathrm{~mm}$ in diameter and 10 mm long

5. Flakes that are already in $1 \mathrm{~mm}$ or smaller will pass through the filter and will come out through the chute. 


\section{Conclusion}

From design process, the chop up mechanism specification can describe as below.

Machine Specification

1. The organic machine enumerator specifications are as follows:

Dimensions of chopper machine: Length $1560 \mathrm{~mm}$, Width $870 \mathrm{~mm}$, Height $1350 \mathrm{~mm}$.

2. Machine Weight $200 \mathrm{~kg}$

3. Production capacity of enumeration $220 \mathrm{~kg} /$ hour, for dry organic matter (moisture content less than $25 \%$ ).

4. The cutting mechanism uses 2 static blades and 6 rotary knives with S50C material

5. Transmission system using 2 units Belts -Pulley mechanism. With V-Belt type B-105.

6. Pulley dimension : 5 inch and 10 inch, Material cast iron Pulley.

7. The Driving force Requirement to rotate the knife and chop material is $20 \mathrm{hp}$.

8. Power drive is Dong Feng diesel Engine, $24 \mathrm{hp}$, with a maximum of $2.200 \mathrm{rpm}$ rotation.

\section{References}

1. Liana and Febriana. Utilization of Agricultural Waste as Ruminant Feed on Community Farmers in Kec. West Rengat Kab. Indragiri Hulu. Jurnal Peternakan Vol 5 No 1, (2837), (2011)

2. E. T. Yuniarsih and M. Basir N. Balai Pengkajian Teknologi Pertanian Sulawesi Selatan. Utilization of Maize Waste as an Eating Feed in South Sulawesi. Seminar Nasional Serealia, (2013).

3. Anita Sari, Liman, and Muhtarudin. Supporting of Agricultural By Product as Ruminant Feed in District Pringsewu Regency. Jurnal Ilmiah Peternakan Terpadu Vol. 4(2): 100107, Mei, (2016).

4. Vaclav Smil. Crop Residues: Agriculture's Largest Harvest: Crop residues incorporate more than half of the world's agricultural phytomass. BioScience, Volume 49, Issue 4, 1 April, Pages 299-308, https://doi.org/10.2307/1313613. (1999)

5. Adeoye, Peter Aderemi, Adebayo, Segun Emmanuel And Musa, John Jiya. Agricultural Post-Harvest Waste Generation And Management For Selected Crops In Minna, Niger State, North Central Nigeria. Journal Sciences and Environmental sanitation Volume 6, Number 4: 427-435, December, (2011)

6. Francisco J. Calderón, Joseph Benjamin, Merle F. Vigi . A Comparison of Corn (Zeamays L.) Residue and Its Bio-char on Soil C and Plant Growth. PLOS ONE | DOI:10.1371/journal.pone.0121006 April 2, (2015)

7. Rifki Zulkarnain, Sugeng Slamet and Taufiq Hidayat, Design Of Hammer Mill Machine Destroying Corn Bongcol With 100kg / Hour Capacity As Animal Feed. Prosiding SNATIF Ke -1 Tahun 2014 ISBN: 978-602-1180-04-4. (2014)

8. Wahyu K Sugandi, Asep Yusuf, Muhammad Saukat.; Design And Performance Test Machine Engine Tube Reel Eye Rey. Design and Test Performance Of Cutter Machines Reel Type for Elephant Grass. Jurnal Teknotan Vol. 10 No. 1, Agustus. P - ISSN :19781067; E - ISSN: 2528-6285. (2016).

9. Honglei Jia, Changying Li, Zhihong Zhang, Gang Wang. J of Bionic Eng 10- 497-505. (2013)

10. I.M.Sanjay Kumar, DR. T.R. Hemanth Kumar Design and Development Of Agricultural Waste Shredder Machine. IJISET - International Journal of Innovative Science, Engineering \& Technology, Vol. 2 Issue 10, October (2015) 